\title{
EGFR NP_005219.2:p.P772_H773insDNP
}

National Cancer Institute

\section{Source}

National Cancer Institute. EGFR NP 005219.2:p.P772 H773insDNP. NCI Thesaurus.

Code $C 98677$.

An insertion of the amino acid sequence aspartic acid-asparagine-proline between the proline at position 772 and the histidine at position 773 of the epidermal growth factor receptor protein. 